УДК 37.036

DOI:

\begin{abstract}
Людмила Лісунова, кандидат педагогічних наук, доиент кафедри українського декоративно-прикладного мистецтва та графіки Харківського національного педагогічного університету імені Г.С. Сковороди
\end{abstract}

\title{
ГРАФІЧНЕ МИСТЕЦТВО ЯК ЗАСІБ ФОРМУ ВАННЯ ЕСТЕТИЧНОГО СПРИЙНЯТТЯ МАЙБУТНІХ УЧИТЕЛІВ ОБРАЗОТВОРЧОГО МИСТЕЦТВА
}

У статті висвітлено багатопланові аспекти вивчення графічного мистецтва як засобу формування естетичного сприйняття майбутніх учителів образотворчого мистечтва. При знайомстві та оволодінні техніками графічного мистеитва у студентів формується прагнення пізнавати історію украӥнської графічноі иколи, вивчати творчість видатних майстрів художньої графіки, активно долучатися до творення нових графічних художніх иінностей. Майбутнім вчителям образотворчого мистецтвва необхідно знати, щчо глибокі емоції, естетичні переживання прекрасного, піднесеного досягаються в графіці тоном паперу, плямою, натиском ліній.

Ключові слова: естетичне сприйняття; майбутні вчителі образотворчого мистецтвв; твори графічного мистецтва; украӥнська графічна школа.

Jim. 8.

Lyudmyla Lisunova, Ph.D.(Pedagogy), Associate Professor of the Ukrainian Decorative Arts and Graphic Arts Department Kharkiv Hryhoriy Skovoroda National Pedagogical University

\section{GRAPHIC ART AS MEANS OF FORMING THE AESTHETIC PERCEPTION OF FUTURE TEACHERS OF FINE ARTS}

The article covers the multifaceted aspects of the study of graphic art as means of forming the aesthetic perception of future teachers of fine arts. With the acquaintance and mastery of graphic arts technicians, the students are determined to learn the history of the Ukrainian graphic school, to study the work of outstanding masters of art graphics, to actively engage in the creation of new graphic artistic values. Graphics - the most popular form of fine arts. The term "graphics" has origins from the ancient Greek verb "grafo", which means "I am writing", "the chair". Depending on how the drawing on the image plane is played, the graphics are distributed to the original and printed. The works of the original graphic are easel works (from the word "machine tool"- an easel, on which a sheet of paper is fixed). A characteristic feature of printed graphics is the possibility of replicating it. This is the feature and advantage of the engraving before the products of the original graphics. The future teachers of fine art need to know that deep emotions, the experience of joys, the amount, the aesthetic experiences of beautiful, are sublime achieved in the graphic tone of paper, paint spot, pressure of the lines, their parallel or cross-grid. However, the contrast between black and white may have a very diverse, substantive and stylistic meaning in the graph: white is light, black is darkness in all transitions and gradations. Study of the graphic heritage of famous graphs of Ukraine is a prerequisite for the formation of aesthetic perception of future teachers of fine arts. The landmark on folk traditions in graphic art was put by wellknown graphic artists who sought to combine the old traditions of Ukrainian art with the new discoveries of European artistic trends. R. Arnheim, B. Edwards, applied to the method of graphic image sensation, giving students the task of drawing human features or emotional states (anger, joy, peace, energy, etc.) using only the language of the lines: fast lines, slow lines, light, dark, smooth, rough, broken. art school.

Keywords: an aesthetic perception; a future teacher of fine art; the works of graphic art; Ukrainian graphic

A ктуальність проблеми та аналіз основних досліджень. Сучасне етапоновлення суспільства вимагає наповнення всіх ланок навчально-виховного процесу, зокрема у вищій педагогічній школі, змістом, який би відображав справжню історію, мистецтво, культуру, символіку, природу рідної України, забезпечував можливості формування творчої, національно свідомої особистості. У Законах України "Про освіту”, “Про вищу освіту”, Концепції громадянського виховання особистості в умовах розвитку української державності, Національній доктрині розвитку освіти у XXI ст. наголошується на необхідності підвищення якості підготовки педагогічних працівників на основі національних традицій та принципів в нових соціокультурних реаліях нашого часу. Серед важливих напрямів розвитку сучасної педагогічної науки $є$ грунтовне дослідження особливостей професійної підготовки майбутніх вчителів образотворчого мистецтва в контексті формування у них естетичного сприйняття 
засобами графічного мистецтва. На думку О.П. Рудницької, традицією вітчизняної мистецької освіти є виявлення емоційно-смислової природи мистецтва, що лежить в основі змісту фахової підготовки та формування естетичного сприйняття майбутнього вчителя образотворчого мистецтва [7].

До питань дослідження естетичного сприйняття мистецтва звертались теоретики P. Арнхейм, I. Зязюн, М. Каган, С. Коновець, Н. Миропольська, В. Маригодова, О. Отич, С.Раппопорт, О. Рудницька, В. Сухомлинський, О. Шевнюк, О. Щолокова, П. Якобсон та ін. Особливості графіки і гравюри в педагогічному процесі розглядалися в працях таких художниківпедагогів як Є. Антонович, Б. Віппер, Н. Радлов, Д. Кардовський, О. Сідоров, В. Фаворський, П. Флоренський, В. Єфименко, М. Резніченко, Я. Твердохлібова. Специфіка технік гравюри виявляється в дослідженнях А. Дюрера, О. Гаврічкова, О. Гончарова, В. Звонцова, Е. Ковтуна, та ін. Проте, значення графічних творів в формуванні естетичного сприйняття майбутніх вчителів образотворчого мистецтва обмежувалося лише вивченням технічних графічних навичок. Тому актуальним $є$ розгляд аспекту розуміння специфіки художньо-образної мови графіки в процесі естетичного сприйняття, аналіз досвіду педагогів графічної школи.

Метою статті $\epsilon$ розкриття можливостей графічного мистецтва як засобу формування естетичного сприйняття майбутніх учителів образотворчого мистецтва.

Виклад основного матеріалу. Мистецтво вища ступінь духовної діяльності суспільства, яка спрямована на естетичне освоєння дійсності. І усі особливості естетичного сприйняття найбільш концентровано виявляються в творах мистецтва. Мистецтво відрізняється тим, що досліджує не одну яку-небудь сторону суспільного життя, як це роблять окремі науки (політекономія, право, мораль, тощо), а всю сукупність суспільних відношень в їх єдності. Мистецтво не замінює ні однієї з форм діяльності людини, а специфічно їх відтворює і дублює [2]. На думку Ф. Аквінського, мистецтво - це переробка людиною матерії, яку він осягає почуттями або розумом в естетичних цілях. Мистецтво відбиває дійсність в художніх образах. Найбільш важливою рисою мистецтва $\epsilon$ здатність його емоційно впливати, збуджувати почуття естетичної насолоди у сприймаючого. Про відношення до зображуваного висловився художник-педагог Ф. Ковальов: “Перед картиною глядач переживає ті ж відчуття, які він переживав і раніше при спогляданні природи, але висловити їх не міг; йому не вистачало слів. Впізнавши свої почуття, виражені художником, глядач буває вражений, втішений, він переживає почугтя світлої радості. Головним завданням художника $є$ створення художнього образу, який і визначає наше емоційне сприйняття твору”. Загальнолюдські цінності і національна самобутність - умови загальносвітового значення твору мистецтва. Немає мистецтва самого по собі, що не несе естетику, мораль, дух народу, вічні його поняття про життя і смерть, добро і зло, минуле, нинішнє і майбутнє, світ, космос тощо.

Одним із видів образотворчого мистецтва, який здатний відчутно впливати на особистість, iii емоційний стан, сприяти культурному та естетичному розвитку, нести чітке смислове навантаження, є графічне мистецтво [8]. Графіка - найпопулярніший вид образотворчого мистецтва. Термін “графіка" має витоки 3 давньогрецького дієслова "графо”, що означає “пишу”, “креслю”. У дитячій творчості завжди є можливість виразити свій задум на папері найбільш доступними графічними матеріалами починаючи з простого олівця. Автори С. Антонович, В. Проців, С. Свид в навчально-методичному посібнику "Художні техніки у школі" зазначили, що дехто вважає, що олівець - малоцікава техніка. Сірий колір штрихів на папері, звичайно, не може рівнятися $з$ привабливістю кольорів у живопису. Але в руках майстра олівець стає знаряддям, яким створюються шедеври [1]. Графічне мистецтво, насамперед, через книжкову графіку, ілюстрації супроводжує людину все життя.

Як зазначив M.I. Резніченко, заняття цим видом мистецтва розвивають у майбутніх спеціалістів навички й уміння використовувати виразні засоби зображення художньо-графічними матеріалами для вирішення різноманітних навчальних i творчих завдань. Вчитель образотворчого мистецтва повинен добре володіти теорією і методикою викладання свого предмета, враховуючи нововведення Болонського процесу, навчати основам графічного мистецтва, уміти виправити роботу учня та показати прийоми роботи різними матеріалами [6]. Мистецтво художньої графіки, і перш за все, рисунок лежить в основі будь-якого зображення. Як зазначив Д.Н. Кардовський, рисунок - це пластична основа мистецтв, які слугують зображенню зорового сприйняття на площині, те основне загальне, що об'єднує всі пластичні або образотворчі мистецтва. Мова графіки - лаконізм, що доводить зорові образи до художньої форми, має сильний вплив на особистість студента. 


\section{ГРАФІЧНЕ МИСТЕЦТВО ЯКЗАСІБ ФОРМУВАННЯ ЕСТЕТИЧНОГОСПРИЙНЯТТЯ МАЙБУТНІХ УЧИТЕЛІВ ОБРАЗОТВОРЧОГО МИСТЕЦТВА}

Графічне мистецтво розвиває емоції і почуття особистості, стимулює художньо-образне мислення студентів, сприяє розкриттю її творчого потенціалу.

Споглядаючи твори художньої графіки, переживаючи в цей момент почуття та емоції, закладені авторами, вбираючи в себе філософський, ідейно-психологічний, і естетичний зміст цих творів, в свідомості студентів виникає естетична оцінка, розвивається творча уява i фантазія. При знайомстві та оволодінні техніками графічного мистецтва у студентів формується прагнення пізнавати історію української графічної школи, вивчати творчість видатних майстрів художньої графіки, таких як П. Беринди, О. Тарасевича, Л. Тарасевича, Г. Левицького, Т. Шевченка, П. Мартиновича, О. Сластьона, Ф. Кричевського, Г. Нарбута, М. Самокиша, М. Пимоненка, О. Мурашки, К. Костенко, О. Куриласа, М. Бойчука, Л. Крамаренка, В. Касіяна та ін., активно долучатися до творення нових графічних художніх цінностей.

Формуючи естетичне сприйняття у майбутніх вчителів образотворчого мистецтва, треба враховувати, що в мистецтві взагалі і в художній графіці зокрема, найбільш концентровано відбивається духовно-практична діяльність людини і включаючись в структуру естетичного сприйняття, воно виявляє такі важливі сторони: розвиток смаків, ідеалів, прагнень, здібностей і потреб особистості на основі гуманізму, як основному принципі мистецтва; усвідомлення естетичної значущості оточуючої дійсності; пробудження творчого духу людини, бажання творити по законам краси, прагнення звільнитися від сірості повсякденного життя; сприяння різносторонній гармонізаціїлюдини, прищепленню прогресивних способів мислення і системи поглядів; прокладання мостів до взаєморозуміння людей різних країн; реагування на зміни в суспільстві; активізування прагнення особистості до самовиховання, до творчої самореалізації; захоплення людини емоційно, мобілізуючи іiі можливості в творчості, труді, сприяти здатності образно сприймати світ; формування менталітету i таких рис характеру особистості як естетизм, чутливість, ліризм, пісенність, м'який гумор. Графічне мистецтво також виявляє важливі для процесу виховання функції, а саме: перетворювальну, компенсаторну, пізнавальноевристичну, художньо-концептуальну, передбачувальну, комунікативну, інформаційну, виховну, надихаючу, естетичну, гедоністичну.

Переглянувши і проаналізувавши студентські роботи, які виконані різними матеріалами і в різних техніках, можна зробити висновок, що зміна матеріалів, їх різне сполучення сприяють розвитку інтересу до творчої роботи. Можливості застосування графіки досить широкі.

В залежності від того, як відтворюється рисунок на зображувальній площині, графіка розподіляється на оригінальну та друковану. Твори оригінальної графіки - це станкові роботи (від слова “станок" - мольберт, на якому закріплюється лист паперу). Такі твори створюються в єдиному екземплярі за допомогою різноманітних олівців, вугілля, сангіни, соусу, пастелі, чорнила, сепії, туші, акварелі, кулькових, гелевих, капілярних ручок, пензлів, паличок, гусячого пір'я, фломастерів, воскових крейд, маркерів.

Характерною особливістю друкованої графіки $\epsilon$ можливість іiі тиражування. Майбутні вчителі образотворчого мистецтва можуть на власному досвіді в графічній майстерні відчути чудову властивість відбитку - естампу (з дерев'яної дошки, металевої пластини, літографічного каменю, лінолеуму) як твору тиражної графіки щодо авторства: те, що зображене в естампі - це справа рук художника - автора твору, навіть, якщо цей лист друкувався на станку та існує у множині відтисків. У цьому особливість та перевага гравюри перед творами оригінальної графіки.

Головна відмінність структури образів, мови графіки від інших видів образотворчого мистецтва полягає в обмеженості засобів у формотворенні [3].

Майбутнім вчителям образотворчого мистецтва необхідно знати, що глибокі емоції, переживання радощів, суму, естетичні переживання прекрасного, піднесеного досягаються в графіці тоном паперу, плямою фарби, натиском ліній, їх паралеллю або перехресною сіткою. Разом 3 тим контраст чорного і білого може мати в графіці саме різноманітне, предметне і стилістичне значення: біле $\epsilon$ світло, чорне - темрява у всіх переходах і градаціях. Контрастом білого паперу і чорної фарби графік може створити враження сліпучої яскравості і глибокого мороку. Білому фону паперу належить активна роль у створенні графічного образу. Це сама міцна, вирішальна властивість графіки. В.А. Фаворський зазначив, що графічне мистецтво, обмежене в більшій частині в своїх засобах чорним і білим, включаючи їх у різноманітні співвідношення один до одного, - досягає власне виразності за допомогою форми плям, різних якостей від чорного до білого [8].

В своїй праці “Візуальне мислення” Р. Арнхейм 


\section{ГРАФІЧНЕ МИСТЕЦТВО ЯКЗАСІБ ФОРМУВАННЯ ЕСТЕТИЧНОГОСПРИЙНЯТТЯ}

МАЙБУТНІХ УЧИТЕЛІВ ОБРАЗОТВОРЧОГО МИСТЕЦТВА

вказував на оригінальну методику формування естетичного сприйняття і мислення студентів на основі використання графічних аналогових рисунків. Рисунки олівцем були призвані дати точний зоровий образ, наприклад, таких понять, як “минуле, теперішнє, майбутнє”. В виконаних студентами запропонованих завданнях, Р. Арнхейм виявив зміни в уміннях студентів від рисунку до рисунку i звернув увагу на поступове відточування поняття, над яким вони працювали, що наближувало до поставлених цілей використовування графічних аналогових малюнків в процесі формування естетичного сприйняття особистості.

До методики графічного зображення відчуттів зверталася Б. Едвардс, даючи завдання студентам намалювати людські риси або емоційні стани (гнів, радість, спокій, енергійність та ін.), використовуючи тільки мову ліній: швидкі лінії, повільні лінії, світлі, темні, гладкі, шершаві, ломані, плавні.

При цьому Б. Едвардс зауважила, що, наприклад, коли людина гнівається або радується, і гнів або радість так і напирає зсередини, проникаючи в вашу руку, потім в долоню руки, в палець і виходить зовні через грифель олівця, щоб самому втілити себе в лініях, які відповідають вашому почуттю, - лінії, які виглядають як почуття, які переживає особистість. Ці аналогові графічні рисунки виявились для Б. Едвардс і їі студентів дуже цінними вправами, тому що вони надають поняттям форму об' єктивного існування і роблять думку видимою, а також дістають на поверхню силу сприйняття особистості.

Графіці можуть бути властиві об'ємнопросторова побудова, оповідання, докладність вивчення натури, виявлення структури предмета. Але художник-графік може обмежитися i швидким враженням, умовною позначкою предмета, ніби натяком на нього, звертаючись до уяви глядача. Смкість образа в графіці часто досягається економією та концентрацією художніх засобів, образотворчими графічними метафорами, що дозволяє порівнювати графіку з поезією. Тому в графіці поряд із завершеними композиціями самостійну художню цінність мають натурні начерки, ескізи творів живопису, скульптури, архітектури. Лінія несе в собі інформацію про зображення, впливаючи на сприйняття особистості. Горизонтальні лінії створюють враження спокою, урівноваженості, тиші. Вертикальні - відчуття висоти, сили, енергії, стрункості. Діагональні - висхідні, активні лінії. Вони надають всій композиції спрямованість, динамічність. Низхідні - пасивність, смуток, печаль. Паралельні - організаційність, строгість, стрункість, злагодженість. Вигнуті, надломлені лінії в графіці використовують для передачі певних емоцій.

Філософ і педагог І.А. Зязюн, зауважив, що педагогічна праця $\epsilon$ особливим видом висококваліфікованої розумової й практичної діяльності творчого, неповторного характеру. І для iï формування першочергового значення набуває мистецтво, особливо його народна традиція [4].

Вивчення графічної спадщини відомих графіків України - необхідна умова формування естетичного сприйняття майбутніх вчителів образотворчого мистецтва. Орієнтир на народні традиції в графічному мистецтві поклали відомі майстри графіки, викладачі першої національної художньої академії, які прагнули поєднати давні традиції українського мистецтва 3 новими відкриттями європейських художніх течій. Завідуючий майстернею графіки, Г. Нарбут надав історичним образам онтологічного статусу, а проблему традиції розглядав як процес засвоєння і розвитку певної спадщини. Всі значущі твори Нарбута поєднують традиції і сучасність. Створення графічних шкіл у Києві, Харкові, Одесі, Львові, їх тісна взаємодія, взаємозбагачення ідеями і пластичними засобами сприяло виникненню такого цілісного явища, як мистецтво нової української графіки. Так В. Кричевський поєднав у своїй творчості два аспекти романтизму - спрямованість у майбутнє і любов до минулого. Його роботи спираються на традиції, що сягають глибин культурної пам'яті, міфології та фольклору. Художньому оформленню книжки присвятили свою творчість О. Кульчицька, Ю. Панькевич, М. Сосенко, Г. Колцуняк. Вони використовували елементи народних орнаментів і стилізацію в дусі старої української гравюри. М. Бойчук як професійний художник переглянув художні надбання давніх культур, найновіші відкриття авангардистів і поєднав їх із традицією українського іконопису, 3 народною картинкою та міським примітивом. О. Сорохтей працював над біблійною тематикою в техніці деревориту. Попри всі відмінності в творчості, всі ці майстри прагнули створити ідеальний образ національного мистецтва, поєднуючи новітні художні мистецькі течії і давні національні традиційні мотиви та форми із залученням взірців мистецтва архаїки, пам'яток середньовіччя [5].

Національна система навчання i, перш за все, формування естетичного сприйняття майбутніх вчителів образотворчого мистецтва покликане забезпечити глибоке осмислення кожним студентом народних традицій, моральних та 


\section{ГРАФІЧНЕ МИСТЕЦТВО ЯКЗАСІБ ФОРМУВАННЯЕСТЕТИЧНОГОСПРИЙНЯТТЯ МАЙБУТНІХ УЧИТЕЛІВ ОБРАЗОТВОРЧОГО МИСТЕЦТВА}

естетичних ідей, положень, правил, принципів, поглядів, сприяти розвиткові й освіченості

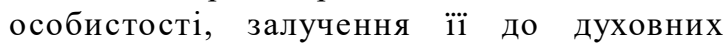
національних і загальнолюдських цінностей, а також до художньо-творчої діяльності. Вивчаючи історію розвитку українського і зарубіжного графічного мистецтва, графічні роботи присвячені народним традиціям, майбутні вчителі образотворчого мистецтва можуть осягнути історичну енергію українського народу, багатство i красу його національного духу, які трансформувалися й акумулювалися в такі графічні твори, як М. Апсіта “Ряджені" 1908 (мал.), К. Кольмана “Балаганні гойдалки” 1820 (акварель), В.Касіяна "Пишуть писанки” 1921, “Маланка" 1926, М. Ткаченка "Папороть" до твору Г. Данилевського “Із українських казок”, 1901 (автотипія); “Кутю проганяють”, 1897 (автотипія); А. Рябушкіна "Гадання дівчат на святках",1885 (гравюра); Х. Гейслера "Ряджені”, 1800 (гравюра); Н. Зубицького “Різдво Христове”, 1709 (дереворіз, Львів); К. Шенберга "Продавець млинців”, 1797 (акватинта); Д. Аткінсона "Водосвяття" та ін.

Оскільки естетичне сприйняття кожного народу розвивається у конкретно-історичних, географічних умовах, його буття поруч із загальнолюдською неодмінно набуває етнічної, народної, ментальної специфіки. Духовний світ та естетична уява українського народу віками складались ущоденному спілкуванні з природою, яка наділила його відчуттям краси, прагненням створювати прекрасні твори світового рівня. Графічне мистецтво увібрало в себе культурноісторичні, природні, ментальні особливості українського народу. Тому естетичне сприйняття, вивчення графічних творів дозволяють виховувати майбутніх учителів образотворчого мистецтва професіоналами та свідомими громадянамипатріотами. Саме такими є графічні роботи О.Кульчицької: “Гагілки”, “Зима і літо”, “Зима”, “Дощ”, “Місяць”, “Різдво Христове”, “Ігри та хороводи на пасхальному тижні на Тернопільщині”.

Висновки. На думку М. Резніченка, в сучасній системі художньо-педагогічної освіти, особливе значення для успішного формування здатностей створювати графічно-художній образ має розвиток емоційного відгуку особистості на основі яскравих зорових уявлень, відчувань, сформованих при вивченні особливостей графічної грамоти, мови відтворення образу та мистецтвознавчого аналізу класичних доробків майстрів графіки минулих століть і сучасності [6].

Графічне мистецтво несе в собі педагогічний потенціал естетико-культурного розвитку студентів, що сприяє різноманітності їх творчих робіт, тематик, сюжетів в практичній роботі, сприяє успішному оволодінню і творчому розумінню студентами естетичного досвіду українського графічного мистецтва. Графіка виступає як елемент чіткої, цілісної системи мистецтва і служить для розвитку дійсно людської чуттєвості, культури та естетичного сприйняття студентів вищої школи.

\section{ЛІТЕРАТУРА}

1. Антонович $Є$. А. Художні техніки в школі / Є.А. Антонович, В.І. Проців, С.П. Свид. - К., 1997. - C. $54-67$.

2. Борев Ю.Б. Эстетика / Ю.Б. Борев. - Ростов на Дону: Феникс, 2004. -704 с.

3. Бойчук В. М. Теоретичні і методичні основи художньо-графічної підготовки майбутнього вчителя технології: автореф. дис. на здобуття наук. ступеню доктора пед. наук: спец.13.00.04. “Теорія та методика професійної освіти” / В.М. Бойчук. - Вінниця, 2017. - 44 с.

4. Зязюн I. А. Педагогічна майстерність / I.А. Зязюн. - К.: Вища шк., 1997. - 120 с.

5. Лагутенко О. А. Українська графіка першої третини XX століття і загальноєвропейські тенденції та національні особливості розвитку: автореф. дис.на здобуття наук. ступеню доктора мистецтвознавства: спец. 17.00.05. “Образотворче мистецтво” / О. А. Лагутенко. - Київ, 2008. - 43 с.

6. Резніченко М.I. Художня графіка: навч.метод. посіб. для студентів художньо-графічних факультетів. / М.І. Резніченко, Я.М. Твердохлібова. - Тернопіль: Навчальна книга - Богдан, 2011. $272 \mathrm{c}$.

7. Рудницька О.П. Мистецтво у професійній підготовці вчителя / О.П. Рудницька // Наукові записки психолого-педагогічного факультету. Полтава, 1997. - Ч.1. - С. 62-66.

8. Фаворский В.А. Об искусстве, о книге, о гравюре / В.А. Фаворский. - М.,1986. - С. 82.

\section{REFERENCES}

1. Antonovych, Ye.A., Protsiv, V.I. \& Svyd, S.P. (1997). Khudozhni tekhniky v shkoli [Art techniques in school]. Kyiv, pp. $54-67$. [in Ukrainian].

2. Borev, Yu.B. (2004). Estetika [Aesthetics]. Rostov on Don: Phoenix, 704 p. [in Russian].

3. Boichuk, V.M. (2017). Teoretychni i metodychni osnovy khudozhno-hrafichnoi pidhotovky maibutnoho vchytelia tekhnolohii [Theoretical and methodological foundations of artistic and graphic preparation of the future teacher of technology]. Extended abstract of Doctor's thesis. Vinnitsa, 44 p. [in Ukrainian]. 
4. Ziaziun, I.A. (1997). Pedahohichna maisternist [Pedagogical skill]. Kyiv: Higher school, 120 p. [in Ukrainian].

5. Lahutenko, O.A. (2008). Ukrainska hrafika pershoi tretyny 20 stolittia i zahalnoievropeiski tendentsii ta natsionalni osoblyvosti rozvytku [Ukrainian graphics of the first third of the twentieth century and general European tendencies and national peculiarities of development]. Extended abstract of Doctor's thesis. Kyiv, 43 p. [in Ukrainian].

6. Reznichenko, M. I. \& Tverdokhlibova, Ya. M. (2011). Khudozhnia hrafika: navch.-metod. posib. dlia studentiv khudozhno-hrafichnykh fakultetiv [Artistic graphics: a manual for students of graphic arts departments]. Ternopil: Educational book, 272 p. [in Ukrainian].

7. Rudnytska, O.P. (1997). Mystetstvo $u$ profesiinii pidhotovtsi vchytelia [Art in the professional training of the teacher]. Scientific notes of the psychological and pedagogical faculty. Poltava, Part 1, pp. 62 - 66. [in Ukrainian].

8. Favorskiy, V.A. (1986). Ob iskusstve, o knige, o gravyure [About art, about the book, about engraving]. Moscow, p. 82. [in Russian].

Стаття надійшла до редакції 04.09.2018

УДК 378.091.212

DOI:

Світлана Булавенко, кандидат педагогічних наук, докторант Інституту проблем виховання НАПН Украӥни, м. Київ

\section{ПІДВИЩЕННЯ ГОТОВНОСТІ ПЕДАГОГІВ ДО ФОРМУВАННЯ СОЦАЛЬНОЇ АКТИВНОСТІ УЧНІВ}

У статті йдеться про актуальність інноваційної діяльності вчителя з формування соціальної активності учнів, розглядається методичний супровід учителів та етапи впровадження програми “Креативний педагог”. Метою даної програми є ознайомлення вчителів з сучасними поглядами на нову стратегію освітньої діяльності в Украӥні та особливості інновачій у сфері освіти та підвищення готовності сучасних інноваційних ресурсів до формування сочіальної активності студентів у професійно-технічній освітній діяльності, мотивація викладачів до професійного розвитку.

Ключові слова: інноваційна діяльність; готовність педагогів до педагогічних інновацій; соиіальна активність; методичний супровід учителів.

Табл. 1. Літ. 6.

Svitlana Bulavenko, Ph.D.(Pedagogy), Doctoral Student of the Institute of Education Problems of the National Academy of Sciences of Ukraine, Kyiv

\section{INCREASING OF READINESS OF TEACHERS TO THE FORMING SOCIAL ACTIVITY OF STUDENTS}

The article deals with the actuality of the teacher's innovative activity on the formation of social activity of students, the methodological support of teachers and the stages of implementation of the program "Creative teacher" is considered, the results of diagnostics of the teachers' readiness for innovation are presented.

Readiness for innovative pedagogical activity on the formation of social activity of the individual is a special personal condition, which involves the teacher's presence of a motivational-value relation to the professional activity, possession the effective means and means of achieving pedagogical goals, an ability to creativity and reflection.

As a result of the analysis of the teacher's innovative activity in the context of improving the readiness and taking into account the general characteristics of the methodological support of this activity, we have developed a program of in-kind training for teachers "Creative Teacher".

The basis of the program's development is the acmeological approach, which reflects the orientation of the process of improving the reader's readiness for innovation in shaping the social activity of the students in the professional development.

The purpose of this program is to familiarize the teachers with the modern views on a new strategy of educational activities in Ukraine and with the features of innovation in education and formation and improve the readiness of the modern innovative resources for the formation of social activity of students in vocational educational activities, motivation of teachers for the professional development.

As practice has shown, the program we have created is an effective for activating the creativity of teachers, for the inclusion of each teacher into the experiment, as systematic classes contribute to increased readiness for innovation in the formation of social activity. 